\title{
The Use of Listening Comprehension Strategies in Distance Language Education
}

\author{
Aysel Deregözü ${ }^{1}$ \\ ${ }^{1}$ School of Foreign Languages, Inonu University, Malatya, Turkey \\ Correspondence: Aysel Deregözü, School of Foreign Languages, Inonu University, Main Campus, 44280 \\ Bulgurlu, Battalgazi/ Malatya, Turkey.
}

Received: August 29, 2021

Accepted: September 17, 2021

Online Published: September 23, 2021

doi: 10.5539/elt.v14n10p62

URL: https://doi.org/10.5539/elt.v14n10p62

\begin{abstract}
This study aims to examine the listening comprehension strategies used by foreign language learners who are learning languages through distance education. It also aims to explore how the use of listening comprehension strategies differs in terms of three variables, namely, gender, L2, and department majored. To do this, the Listening Strategy Inventory was administered to students attending English and German language classes through distance education at three state universities in Turkey. The data were collected during the 2020-2021 academic year. The study used quantitative analysis methods. The data were analyzed with descriptive statistics and the statistical analyses independent samples t-test. The findings revealed that students use listening comprehension strategies at a moderate level. The most commonly used listening comprehension strategies were those for while listening and nonverbal strategies, while learners use word-oriented strategies the least. The study also revealed statistically significant differences by gender in foreign language learners' listening comprehension strategies, but no significant differences for department majored and L2 variables. It is recommended that individual differences be considered when teaching listening comprehension strategies to foreign language learners.
\end{abstract}

Keywords: listening comprehension, strategy, foreign language learning, distance education

\section{Introduction}

Listening comprehension is vitally important for oral communication, as it plays a key role in determining the course of conversation in the communication process. In this process, a verbal or nonverbal reaction is given depending on the spoken message, allowing communication to continue and take place as desired. Listening comprehension is important not only for maintaining effective communication but also for obtaining information. As pointed out by Hunsaker (1990), "An estimated $80 \%$ of what we know is acquired through listening" (cited by Swaine, Friehe, \& Harrington, 2004, p. 48). Moreover, of the four language skills, listening is placed and carried out at the first stage of the learning process, and the early stages of language development in one's first language are dependent on listening comprehension (Gestanti, 2017).

Listening comprehension is crucial for the development not only of the first but also the second language because with listening, the learner obtains information on the phonology, lexis, syntax, semantics, and discourse structure of the target language and establishes the foundation of speaking in a foreign language. It is stated that roughly more than half the time that students spend in learning a foreign language is allocated to listening (Nation \& Newton, 2009, p. 37; cited by Gestanti, 2017). Nevertheless, listening is considered to be a "highly complex problem-solving activity" (Byrnes, 1984; cited by Osada, 2004, p. 55), which means that it requires specific techniques and strategies that facilitate this activity.

Listening comprehension and strategies have been the topic of many studies to date. These studies mainly focus on listening strategies used in face-to-face education (Thomson \& Rubin, 1996; Seferoğlu \& Uzakgören, 2004; Graham \& Macaro, 2008; Bidabadi \& Yamat 2011; Bozorgian \& Pillay, 2013; Dalman, 2016). However, it is well-known that with the outbreak of the COVID-19 pandemic in the year 2020, education has been widely conducted via distance education with the result that face-to-face education has ended partly or fully, and online platforms are used to continue education. Therefore, the key question is: How does this form of teaching affect the use of listening strategies? Notably, in language education, learners' language learning has been constrained by the opportunities these platforms offer and by the evident lack of face-to-face interactions, considered to be of 
vital importance for the development of communication competencies in a foreign language. It is in this context that this study aims to explore the extent to which learners make use of listening strategies when learning a language through distance education.

\subsection{Literature Review}

Listening is defined as "the mental process of constructing meaning from spoken input" (Rost, 2002, p. 279; cited by Yükselci, 2004, p. 9) or "the action of attentively hearing activity" (Farlex, 2007, p. 2; cited by Gestanti, 2017, p. 37). But in a broad sense, listening is described as "a process of receiving what the speaker actually says (receptive orientation); constructing and representing meaning (constructive orientation); negotiating meaning with the speaker and responding (collaborative orientation); and creating meaning through involvement, imagination, and empathy (transformative orientation)" (Rost, 2002; cited by Vandergrift, 2003). Hence, it can be identified "as an active process in which listeners select and interpret information that comes from auditory and visual clues in order to define what is going on and what the speakers are trying to express" (Thompson \& Rubin, 1996, p. 331). Nevertheless, listening comprehension is regarded as vital for gaining input out of what has been heard.

"In terms of language teaching, listening refers to an activity that allows students to understand a spoken language. It is the process of receiving what the speaker states, understanding and expressing meaning, reasoning the meaning and giving a response, and lastly, generating meaning through participation, imagination, and understanding" (Gilakjani \& Ahmadi, 2011, p. 978). In foreign language education, of the four language skills, namely, listening, reading, writing, and speaking, listening is accepted as a receptive skill. As the word receptive implies a passive state, one might assume that listening is not a productive act like its counterpart, speaking. However, this is not the case because it "involves the process of making sense by receiving and processing external data" (Tanrıkulu \& Çiftçi, 2019, p. 233) and that means listening is not merely hearing something; rather, it requires the skills of "understanding, paying attention, analyzing, evaluating the spoken messages, and acting on what is heard and what is intended" (Khamdani, 2014, p. 14; cited by Gestanti, 2017, p. 38). Beyond the fact that the receiver is receptive, as he receives the verbal message, he is productive, as the message is decoded, analyzed, evaluated, and reproduced. Therefore, listening is widely acknowledged "as an active skill that involves many processes" (Osada, 2004, p. 55).

However, listening comprehension is regarded to be "the least explicit and the most difficult language skill to tackle with." (Rahimi \& Abedi, 2014, p. 1454). One of the difficulties of listening is that to comprehend spoken messages, the "listeners need to integrate information from a range of sources such as phonetic, phonological, prosodic, lexical, syntactic, semantic, and pragmatic" (Osada, 2004, pp. 55-56). In addition, listening involves "attention to a continuous stream of speech which is not under the timing control of the listener" (McDonough, 1995, p. 34; cited by Osada, 2004, p. 60). As pointed out by Osada (2004), the listener tries to decipher the utterance in a limited time by consulting his prior knowledge and passing the speech through a mental process. However, the processing space is limited and before someone can sort out what has been heard, the speech disappears and the speech cannot be repeated. Hence, what has been heard needs to be retained in memory, integrated with what follows, and continually adjusted to the listener's understanding in the light of prior knowledge and incoming information. Moreover, when listening to a foreign language, students' limited vocabulary frequently impedes listening comprehension, and "it can be very challenging to concentrate in a foreign language" (Underwood, 1989; cited by Gestanti, 2017, p. 40). Hence, it can be inferred that listening comprehension remains a challenging matter for language learners because they need to decipher the spoken language in a limited time. In this process, listening comprehension strategies might facilitate the understanding of spoken language in a foreign language.

Language learning strategies are described in various ways (Deregözü \& Üstün, 2021). In a broad sense, it can be defined as "techniques consciously used by learners to improve their progress in acquiring, storing, retaining, and using information in a second or foreign language" (Y1lmaz, 2010, p. 683) and "the implementation of a set of procedures or tactics to accomplish something" (Oxford, 2003, p. 2; cited by Gestanti, 2017). Strategies can help and facilitate to achieve, recall, retrieve, and utilize the information (Chang, Liu, \& Lee, 2007). It can also determine students' success because learners use strategies to deal with the difficulties of language tasks (Celce-Murcia, 2001; cited by Gestanti, 2017).

Research has shown that good listeners employ a variety of strategies (O’Malley, Chamot, \& Küpper, 1989). These strategies are mainly classified under the categories metacognitive, cognitive, and socio-affective strategies (Vandergrift, 1997; O'Malley \& Chamot, 1990). Cognitive strategies are defined as those "which interact with text information directly through recall, identification, analysis and response in order to comprehend a given text" (Kyoko, 2002, p. 68), and metacognitive strategies are "conscious strategies that relate 
to listeners' awareness of how to regulate, plan and monitor their cognition, and learner's ability to evaluate their comprehension" (Kyoko, 2002, p. 68). Socio-affective strategies are defined "as the techniques listeners use to collaborate with others, to verify understanding or to lower anxiety" (Vandergrift, 2003).

Yükselci (2003), on the other hand, claims a diverse classification and suggests employing the direct and indirect language learning strategies developed by Oxford (1990) for listening. Direct language learning strategies include memory-related strategies, cognitive strategies, and compensatory strategies. Indirect language learning strategies include metacognitive strategies, affective strategies, and social strategies.

Hence, there are a number of listening techniques and strategies that can be classified under various categories. However, when studies on listening comprehension strategies are examined, it is evident that most of the strategies defined can be applied at the pre-, while-, and post-listening stages. These strategies make it easier to perform the listening tasks as desired.

\subsection{Importance of the Study}

Listening comprehension has been largely neglected in research and practice compared with the other skills (Yükselci, 2003; Osada, 2004). Studies on listening comprehension in foreign language education focus mainly on teaching listening strategies to learners and their effect on listening comprehension in traditional classroom settings (Thomson \& Rubin, 1996, Seferoğlu \& Uzakgören, 2004; Graham \& Macaro 2008; Bidabadi \& Yamat 2011; Bozorgian \& Pillay, 2013; Dalman, 2016). However, studies examining listening comprehension strategies in online language education are limited. Additionally, it should be noted that listening comprehension strategies also cover obtaining information from "nonverbal cues, like facial expression, nods, gestures, or tone of voice" (Osada, 2003, p. 62). These cues are easy to grasp in face-to-face interactions, but difficult to grasp in online learning settings. Listening in the classroom is also shaped by the rapid talking rates of teachers and noise distractions, regarded as posing considerable challenges for learners (Swaine, Friehe, \& Harrington, 2004); however, in online education, these challenges might not be the case. Hence, it can be said that the circumstances of listening in the classroom differ from listening to online courses through distance education. Therefore, which listening strategies are preferred by learners who attend online language classes through distance education needs to be investigated. Moreover, it is also stated that there are few studies examining the listening comprehension strategies in foreign languages other than English. The studies relating to English focus more on teaching listening strategies rather than trying to understand the strategies that learners are already aware of (Noroozi, Sim, Nimechisalem, \& Zareian, 2014).

\subsection{Aim of the Study}

This study aims to investigate the use of listening comprehension strategies by students who receive online foreign language education through distance education. Furthermore, it aims to determine the extent to which the listening strategies used by learners who receive online foreign language education differ with respect to the variables of gender, department majored, and L2.

To this end, answers to the following research questions are sought:

1) Are there any significant differences in foreign language learners' use of listening comprehension strategies by gender?

2) Are there any significant differences in foreign language learners' use of listening comprehension strategies by department majored?

3) Are there any significant differences in foreign language learners' use of listening comprehension strategies by L2?

\section{Method}

\subsection{Participants}

The study was conducted in the 2020-2021 academic year with 114 university students attending English and German classes via distance education at three state universities in Turkey. The participants were randomly selected. The students participating in the sampling were selected using the simple random sampling method. In this way, each sampling unit was sampled by giving an equal probability of being selected (Büyüköztürk, Kılıç Çakmak, Akgün, Karadeniz, \& Demirel, 2013). Of the participants, 70 (60.9\%) were female and 44 (38.6\%) were male; $90(78.9 \%)$ were attending the preparatory class and $24(32 \%)$ were on a bachelor program; 73 (63.5\%) were enrolled in a language-related department such as the departments of English language teaching, German language teaching, or English language and literature; 41 (35.7\%) participants were enrolled in a non-language related department such as political sciences and international relations, engineering, or management, 67(58.3\%) were attending German classes and 47 (40.9\%) English classes via distance education. 


\subsection{Instruments}

The study used the "Oral Communication Strategy Inventory" developed by Nakatani (2006) and adapted into Turkish by Irgin (2011) as the "Listening Strategy Inventory." The Listening Strategy Inventory is a 5-point Likert scale ranging between "Never true of me" and "always true of me." The inventory includes 21 items and consists of five factors. The 1 st factor (items $5,11,16,19,20,21$ ) covers negotiation for meaning while listening strategies; the 2nd factor (item 8, 9, 10,14, 15, 17) covers getting the gist strategies; the 3rd factor (item 1, 6, 12, 18 ) is scanning strategies; the 4th factor (items $2,7,13$ ) covers nonverbal strategies, and the 5 th factor (item, 3,4 ) is word-oriented strategies. The reliability levels of the inventory in the adaptation study were found to be $.82, .76, .67, .61$, and .74 , respectively. In this study, the reliability level was found to be .86 for the entire inventory.

\subsection{Data Collection and Analysis}

The Listening Strategy Inventory (Irgin, 2011) was administered to students at the end of the semester by sending them the inventory online. The data were analyzed using the PASW 18.00 statistical package program. The Independent Samples t-Test was applied to determine differences by variable. Furthermore, descriptive statistics were used to determine frequencies, percentages, and mean averages. The findings are presented in the tables below.

\section{Results}

\subsection{Descriptive Statistics Results for Use of Listening Strategies}

Table 1 shows the results of the descriptive statistics for the use of listening comprehension strategies.

Table 1. Descriptive statistics results for use of listening comprehension strategies

\begin{tabular}{llllll}
\hline & $\mathrm{N}$ & Min & Max & Mean & SD \\
\hline Negotiation for meaning while listening strategies & 114 & 1.67 & 5.00 & 3.80 & .67 \\
Getting the gist strategies & 114 & 1.50 & 5.00 & 3.72 & .68 \\
Scanning strategies & 114 & 2.25 & 5.00 & 3.75 & .64 \\
Nonverbal strategies & 114 & 1.67 & 5.00 & 3.80 & .73 \\
Word-oriented strategies & 114 & 1.50 & 4.50 & 3.39 & .65 \\
LSU & 114 & 2.00 & 4.86 & 3.73 & .54 \\
\hline
\end{tabular}

Table 1 shows that the negotiation for meaning while listening strategies and nonverbal strategies categories have the highest mean value with an average of 3.80, and the word-oriented strategies category has the lowest mean value with an average of 3.39.

\subsection{Use of Listening Comprehension Strategies by Gender}

Table 2 shows the results of the Independent Samples t-Test, which was applied to find out whether there were any significant differences in the use of listening comprehension strategies by gender.

Table 2. Independent Samples t-Test results for use of listening comprehension strategies by gender

\begin{tabular}{lllllll}
\hline & Group & $\mathrm{N}$ & $\overline{\mathrm{x}}$ & $\mathrm{SD}$ & t-value & Sig. \\
\hline Negotiation for meaning while & Female & 70 & 3.97 & .60 & 3.41 & $.001^{*}$ \\
listening strategies & Male & 44 & 3.53 & .71 & & \\
Getting the gist strategies & Female & 70 & 3.91 & .58 & 3.66 & $.000^{*}$ \\
& Male & 44 & 3.43 & .72 & & \\
Scanning strategies & Female & 70 & 3.88 & .62 & 2.86 & $.005^{*}$ \\
& Male & 44 & 3.53 & .63 & & \\
Nonverbal strategies & Female & 70 & 3.97 & .71 & 2.85 & $.005^{*}$ \\
& Male & 44 & 3.57 & .71 & & \\
Word-oriented strategies & Female & 70 & 3.46 & .58 & 1.54 & .128 \\
& Male & 44 & 3.26 & .74 & & \\
LSU & Female & 70 & 3.88 & .48 & 4.09 & $.000^{*}$ \\
& Male & 44 & 3.48 & .55 & & \\
\hline$<.05$ & & & & & &
\end{tabular}


Table 2 shows that the mean values for use of listening comprehension strategies was $(\overline{\mathrm{x}}=3.88)$ for females and $(\overline{\mathrm{x}}=3.48)$ for males. When the mean scores of the two groups are compared, it can be seen that significant differences are at $* \mathrm{p}<.05$ level $(\mathrm{p}=.000)$ in favor of females. According to these findings, it is evident that females tend to use more listening comprehension strategies than males.

\subsection{Use of Listening Comprehension Strategies by Department Majored}

Table 3 shows the Independent Samples t-Test results for use of listening comprehension strategies by department majored.

Table 3. Independent Samples t-Test results for use of listening comprehension strategies by department majored

\begin{tabular}{lllllll}
\hline & Group & $\mathrm{N}$ & $\overline{\mathrm{x}}$ & $\mathrm{SD}$ & $\mathrm{t}$-value & Sig. \\
\hline Negotiation for meaning & General & 41 & 3.83 & .67 & -.40 & .692 \\
while listening strategies & Foreign Languages & 73 & 3.78 & .68 & & \\
Getting the gist strategies & General & 41 & 3.65 & .68 & .86 & .392 \\
& Foreign Languages & 73 & 3.76 & .68 & & \\
Scanning strategies & General & 41 & 3.77 & .63 & -.36 & .723 \\
& Foreign Languages & 73 & 3.72 & .65 & & \\
Nonverbal strategies & General & 41 & 3.76 & .74 & .55 & .582 \\
& Foreign Languages & 73 & 3.84 & .73 & & \\
Word-oriented strategies & General & 41 & 3.26 & .69 & 1.55 & .123 \\
& Foreign Languages & 73 & 3.46 & .62 & & \\
LSU & General & 41 & 3.70 & .55 & .38 & .705 \\
& Foreign Languages & 73 & 3.74 & .54 & & \\
\hline $\mathrm{p}<.05$ & & & & & &
\end{tabular}

From Table 3, it can be seen that there were no statistically significant differences for the use of listening comprehension strategies by department majored $(\mathrm{p}=.705)$.

3.4 Use of Listening Comprehension Strategies by L2

Table 4 shows the results for use of listening comprehension strategies by L2.

Table 4. Independent Samples t-Test results for use of listening comprehension strategies by L2

\begin{tabular}{lllllll}
\hline & Group & $\mathrm{N}$ & $\overline{\mathrm{x}}$ & $\mathrm{SD}$ & $\mathrm{t}$-value & Sig. \\
\hline Negotiation for meaning & German & 67 & 3.75 & .68 & .962 & .339 \\
while listening strategies & English & 47 & 3.87 & .67 & & \\
Getting the gist strategies & German & 67 & 3.74 & .69 & .236 & .814 \\
& English & 47 & 3.71 & .67 & & \\
Scanning strategies & German & 67 & 3.70 & .67 & -.871 & 385 \\
& English & 47 & 3.81 & .61 & & \\
Nonverbal strategies & German & 67 & 3.83 & .75 & .327 & .744 \\
\multirow{3}{*}{ Word-oriented strategies } & English & 47 & 3.78 & .71 & & \\
& German & 67 & 3.45 & .64 & 1.21 & .228 \\
LSU & English & 47 & 3.30 & .66 & & \\
& German & 67 & 3.72 & .55 & -.248 & .806 \\
& English & 47 & 3.74 & .54 & & \\
\hline
\end{tabular}

$* \mathrm{p}<.05$

Table 4 shows there were no statistically significant differences for use of listening comprehension strategies by $\mathrm{L} 2(\mathrm{p}=.806)$ 


\section{Discussion}

Listening comprehension strategies facilitate L2 listening. But how are these specific strategies used by learners who receive foreign language education via distance education? This study, which was carried out to explore this issue, revealed that learners, on average, use listening comprehension strategies at a medium level. The most commonly used listening comprehension strategies are the strategies for while listening and nonverbal strategies, but learners use word-oriented strategies the least (see Table 1). The study also revealed that foreign language learners' use of listening comprehension strategies showed statistically significant differences by gender, but no significant differences by department majored and L2.

When these findings are compared with prior research findings, it can be seen that the findings related to gender were not in line with prior research findings where differences in the use of listening strategies were found to be minimal (1997). Furthermore, the study revealed there was no significant differences in students' use of listening strategies by department majored. However, it is stated that in the example of English-related departments, "students in non-English departments encounter greater difficulties in learning English as they have a shorter time in direct contact with or using the language" (Gestanti, 2017, p. 37). It is stated that "they are not fully aware of their English learning or how they can obtain the optimal learning result by using their strategies." (Gestanti, 2017, p. 37). From this statement, it can be inferred that students of non-foreign language-related departments tend not to utilize listening comprehension strategies, unlike students of foreign language-related departments. However, this study revealed no significant differences between students' use of listening comprehension strategies in foreign language and non - foreign language-related departments. The reason for this might lay in the sample because most of the participants were attending preparatory classes and were getting equal online language education. Hence, they were equally exposed to language education because face-to-face interaction was at a minimum level due to distance education. This fact could also explain the result that there were no significant differences in terms of L2. Since what most learners of the German language have in common is the fact that they already know another foreign language, which is in general English, it can be asked why these learners have not transferred their learning experiences in the first foreign language. In other words, these students are supposed to have prior knowledge in using strategies for listening comprehension because they are more experienced in language learning. This matter needs to be investigated further. Future studies might explore learners' use of listening comprehension strategies in first and second languages, their transferability, and their interrelation.

The literature suggests raising awareness of the native language listening strategies that learners already use, so they can transfer these strategies to L2. It emphasizes encouraging students "to adopt more native-like processing strategies" (Berne, 2004, p. 522). As stated, "training in the use of listening strategies facilitates L2 listening comprehension" (Rubin, 1990; cited by Berne, 1998, p. 170). Therefore, learners should be aware of strategies they already use and of strategies they can use for listening comprehension in a foreign language. Moreover, as stated by Vandergrift (2003), "L2 listening competence is a complex skill that needs to be developed consciously" and "it can be best developed with practice when students reflect on the process of listening without the threat of evaluation" (Vandergrift, 2003). Hence, "L2 learners can and should be taught how to use listening strategies" (Berne, 1998, p. 170). Another point to be considered is that "while learners may follow a similar sequence in applying listening strategies, individual differences still occur" (Berne, 2004, p. 522) and that "learners vary in terms of their repertoires of strategies and how they apply the strategies available to them" (Berne, 2004, p. 529). Hence, individual differences need to be considered while creating awareness of and fostering the acquisition of diverse listening comprehension strategies. Based on the literature, it can be recommended "to increase the amount of listening time in the second language class, use listening before other activities, include both global and selective listening, activate high-level skills (e.g., giving advance organizers or script activators), work towards automation in processing, and develop conscious listening strategies" (Peterson 2001; cited by Yıldırım \& Yildırım, 2016, p. 2104). Furthermore, "learners should be encouraged to develop listening strategies that focus more on prosodic and semantic cues and less on syntactic cues" (Berne, 2004, p. 522).

Although the instrument employed limits this study, it gives evidence that learners who learn a language via distance education need guidance from instructors regarding listening comprehension strategies so they can apply the strategies properly in language learning. The small sample in the present study makes it difficult to generalize the findings to the entire population of foreign language learners in Turkey. However, it does give clues on learners' use of listening comprehension strategies via distance education. Furthermore, studies with a greater sample size are recommended to obtain more insight into learners' preferences regarding the use of listening comprehension strategies. 


\section{References}

Berne, J. E. (1998). Examining the relationship between L2 listening research, pedagogical theory, and practice. Foreign Language Annals, 31, 169-190. https://doi.org/10.1111/j.1944-9720.1998.tb00566.x

Berne, J. E. (2004). Listening comprehension strategies: A review of the literature. Foreign Language Annals, 37(4), 521-531. https://doi.org/10.1111/j.1944-9720.2004.tb02419.x

Bidabadi, F. S., \& Yamat, H. (2011). The relationship between listening strategies used by Iranian EFL freshmen university students and their listening proficiency levels. English Language Teaching, 4(1), 26-32. https://doi.org/10.5539/elt.v4n1p26

Bozorgian, H., \& Pillay, H. (2013). Enhancing foreign language learning through listening strategies delivered in L1: An experimental study. International Journal of Instruction, 6(1), 105-122.

Büyüköztürk, Ş., Kılıç Çakmak, E., Akgün, Ö. E., Karadeniz, Ş., \& Demirel, F. (2013). Bilimsel araştırma yöntemleri, 15. Bask1, Pegem Akademi.

Chang, C. Y., Liu, S., \& Lee, Y. (2007). A study of language learning strategies used by college EFL learners in Taiwan. Language Learning, 3, 235-262.

Dalman, M. R. (2016). The relationship between listening anxiety, listening comprehension strategies, and listening performance among Iranian EFL University students. International Journal of Modern Language Teaching and Learning, 1(6), 241-252.

Deregözü, A., \& Üstün, B. (2021). A comparative study of reading strategies used by prospective language teachers. International Online Journal of Education and Teaching (IOJET), 8(2), 1250-1262.

Gestanti, R. A. (2017). Listening strategies employed by non- English department students. Journal on English as a Foreign Language, 7(1), 35-58. https://doi.org/10.23971/jefl.v7i1.485

Gilakjani, A. P., \& Ahmadi, M. R. (2011). A study of factors affecting EFL learners' English listening comprehension and the strategies for improvement. Journal of Language Teaching and Research, 2(5), 977-988. https://doi.org/10.4304/jltr.2.5.977-988

Graham, S., \& Macaro, E. (2008). Strategy instruction in listening for lower-intermediate learners of French. Language Learning, 58(4), 747-783. https://doi.org/10.1111/j.1467-9922.2008.00478.x

İrgin, P. (2011). Listening strategies used by Turkish students learning English as a foreign language: The development of "Listening Strategy Inventory." (Unpublished master thesis). Mersin University, Mersin, Turkey.

Kyoko, S. (2002). Research Note: The Effect of Visuals on Listening Comprehension: A Study of Japanese Learners' Listening Strategies. International Journal of Listening, 16(1), 57-81. https://doi.org/10.1080/10904018.2002.10499049

Noroozi, S. S., Sim, T. S., Nimehchisalem, V., \& Zareian, G. (2014). Developing an instrument for Iranian EFL learners' listening comprehension problems and listening strategies. Advances in Language and Literary Studies, 5(3), 63-69. https://doi.org/10.7575/aiac.alls.v.5n.3p.63

O’Malley, J. M., \& Chamot, A. U. (1990). Learning strategies in second language acquisition. New York: Cambridge University Press. https://doi.org/10.1017/CBO9781139524490

O'Malley, J. M., Chamot, A. U., \& Kupper, L. (1989). Listening Comprehension Strategies in Second Language Acquisition. Applied Linguistics, 10(4), 419-437. https://doi.org/10.1093/applin/10.4.418

Osada, N. (2004). Listening comprehension research: A brief review of the past thirty years. Dialogue, 3, 53-66. https://doi.org/10.4324/9780203317730-12

Rahimi, M., \& Abedi, S. (2014). The relationship between listening self-efficacy and metacognitive awareness of listening strategies. Procedia, Social and Behavioral Sciences, 98, 1454-1460. https://doi.org/10.1016/j.sbspro.2014.03.565

Seferoğlu, G., \& Uzakgören, S. (2004). Equipping learners with listening strategies in English language classes. Hacetettpe University Journal of Education Faculty, 27, 223-231.

Swain, K. D., Friehe, M., \& Harrington, J. M. (2004). Teaching Listening Strategies in the inclusive classroom. Intervention in School and Clinic, 40(1), 48-54. https://doi.org/10.1177/10534512040400010401 
Tanrıkulu, L., \& Çif̧̧i, H. (2019). The analysis of productive skills in foreign language teaching methods. International Journal of Academy, 7(4), 232-245. https://doi.org/10.29228/ijla.39870

Thompson, I., \& Rubin, J. (1996). Can strategy instruction improve listening comprehension? Foreign Language Annals, 29(3), 331-342. https://doi.org/10.1111/j.1944-9720.1996.tb01246.x

Vandergrift, L. (2003). Listening: theory and practice in modern foreign language competence. Retrieved from $\mathrm{https://www.llas.ac.uk/resources/gpg/67}$

Vandergrift, L. (2008). The comprehension strategies of second language (French) listeners: A descriptive study. Foreign Language Annals, 30(3), 387-409. https://doi.org/10.1111/j.1944-9720.1997.tb02362.x

Yıldırım, S., \& Yıldırım, Ö. (2016). The importance of listening in language learning and listening comprehension problems experienced by language learners: A literature review. Abant Izzet Baysal Journal of Education Faculty, 16(4), 2094-2110.

Y1lmaz, C. (2010). The relationship between language learning strategies, gender, proficiency, and self-efficacy beliefs: a study of ELT learners in Turkey. Procedia Social and Behavioral Sciences, 2(2), 682-687. https://doi.org/10.1016/j.sbspro.2010.03.084

Yükselci, S. (2003). Teachers' practices and perceptions regarding listening strategies, and perceptions of difficulties likely to arise in English listening comprehension lessons. (Unpublished Master Thesis), Bilkent University, Ankara, Turkey.

\section{Copyrights}

Copyright for this article is retained by the author(s), with first publication rights granted to the journal.

This is an open-access article distributed under the terms and conditions of the Creative Commons Attribution license (http://creativecommons.org/licenses/by/4.0/). 